\title{
Assessing the toxicities of the binary mixtures of sodium dodecyl sulfate and heavy metals to Serratia marcescens (SerEW01) from Otamiri River
}

\author{
Okechi, R.N. ${ }^{*}$, Chukwura, E.I. ${ }^{2} \&$ Nweke, C.O. ${ }^{3}$ \\ ${ }^{1}$ Department of Biotechnology, Federal University of Technology Owerri, Imo State, Nigeria \\ ${ }^{2}$ Department of Applied Microbiology and Brewing, Nnamdi Azikiwe University, Awka, Anambra State, Nigeria \\ ${ }^{3}$ Department of Microbiology, Federal University of Technology Owerri, Imo State, Nigeria
}

Received August 11, 2020; Accept September 16, 2021

\begin{abstract}
Toxicities of sodium dodecyl sulfate (SDS) + Pb(II), SDS + Cd(II), SDS + Ni(II), SDS + Zn(II), and SDS + Co(II) binary mixtures to Serratia marcescens (SerEW01) isolated from Otamiri river water, Owerri, Imo State, Nigeria were undertaken, using dehydrogenase activity as a response. Inhibitions of dehydrogenase activity by the individual toxicants were concentrationdependent, increasing steadily as the concentration increases. The observed $E C_{50 \mathrm{~S}}$ ranged from $0.046 \pm 0.003 \mathrm{mM}$ for $\mathrm{Zn}$ (II) to $2.329 \pm 0.092 \mathrm{mM}$ for SDS. Duncan tests indicated that the $E C_{50 \mathrm{~s}}$ of the individual toxicants differed significantly from each other. The order of decreasing toxicities was $\mathrm{Zn}(\mathrm{II})>\mathrm{Cd}(\mathrm{II})>\mathrm{Co}(\mathrm{II})>\mathrm{Ni}(\mathrm{II})>\mathrm{Pb}(\mathrm{II})>\mathrm{SDS}$. Fixed ratio mixtures [Arbitrary concentration ratio (ABCR) and $E C_{50}$ equieffect concentration ratio (EECR 50)] were used to study the joint action of the binary mixtures. The mixtures progressively inhibited dehydrogenase activity in $S$. marcescens as the concentration increases. However, SDS $98.08 \%$ + Co(II) $1.92 \%$ mixture ratio was biphasic. The effects of the mixtures on the dehydrogenase activity were assessed using Toxic Index, Model Deviation Ratio and Isobolographic analyses. In addition, the toxicities of the mixtures were predicted with concentration addition (CA) and independent action (IA) models. In SDS+Ni(II) binary mixture, both models predicted similar toxicities. In all binary mixtures, both models greatly underestimated the mixture toxicities compared to the experimentally-observed data. Similarly, both the experimentally-observed, CA and IA-predicted $E C_{50 \mathrm{~s}}$ were statistically different from each another. Furthermore, the binary mixtures were generally synergistic against $S$. marcescens (SerEW01). This demonstrates the potential danger of co-contamination of the aquatic system by SDS and heavy metals
\end{abstract}

Keywords: Heavy metals, surfactants, mixture, toxicity, synergism, predictive models

\section{INTRODUCTION}

Environmental pollution by chemicals such as surfactants and heavy metals are as a result of increasing industrial human activities. The penetration of large amounts of these pollutants into surface water reservoirs could result in foaming, reduction in diffusion of atmospheric oxygen that dissolve in water and consequently lead to the death of many aquatic organisms due to deficiency of oxygen (Seifert \& Domka, (2005). Sodium dodecyl sulfate (SDS) is an anionic surfactant commonly used in industrial, agricultural and domestic detergents and therefore, is a common contaminant of aquatic environments, through contaminated waters, sediments, or soils, thus threatening portable water sources, aquatic organisms or both (Singer \& Tjeerdema, 1993; Cowan-Ellsberry et al., 2014). Toxic metals from various sources could also contaminate surface and ground water sources. Apart from natural sources, anthropogenic activities that have contributed to heavy metals environmental 
contamination include but not limited to metal mining, battery industry, burning of organic fuels, electroplating, electronics production, oil and petrochemicals spillage, as well as various agricultural practices (Chaturvedi \& Tiwari 2013).

The toxicity of chemical compounds on aquatic organisms has been reported to be dependent on the concentrations of the chemicals in both sediments and the overlaying water, as well as in processes that relates to their bioavailability. Furthermore, such processes as bioaccumulation, biodegradation, desorption and solubilization which take place in these substrata determine the quantity of the bio-available compounds that will reach toxic levels in the organs of organisms living in aquatic environment (Flores et al., 2010). Microbes are indispensable for the normal functioning of the ecosystem; hence parameters that influence their metabolic activities and diversity should be of great interest. Microbes are known for their prompt responses to environmental perturbations, thus evaluation of microbial responses has been suggested as an immediate sign of ecosystem disturbances (Griffiths, 1983).

Otamiri River in Imo State, Nigeria is the major river serving Owerri and environs as a source of water for drinking, other domestic activities, fishing, urban agriculture, recreation and sand mining. It equally receives various types of man-made pollutants of industrial, agricultural and domestic origin, through run-offs and untreated sewage. Similarly, solid wastes from Owerri urban and environs are also dumped and incinerated along the river bank. These activities have resulted in the contamination of the river water and sediment by both anionic surfactants and some heavy metals (Okechi \& Chukwura, 2020). So far, many studies have been conducted on the bacteriological quality as well as heavy metals contamination of the river and its sediment (Onyekuru et al., 2017; Oga et al., 2018; Okechi \& Chukwura, 2020). Sodium dodecyl sulfate (SDS) was reported to be the dominant anionic surfactant in Otamiri river water and sediment. Serratia marcescens has also been reported in Otamiri river by Ogbulie et al. (2008). Similarly, Serratia marcescens (SerEW01) was reported to be the preponderant bacterium among the bacterial population in the river water (Okechi \& Chukwura, 2020). This high level of SDS contamination of Otamiri River may have led to possible selection of this bacterium in the river. Furthermore, SDS utilization as carbon and energy source by Serratia marcescens has been reported (Fedeila et al., 2018; Ahmad et al., 2019). The toxicological responses of the bacterial population of this aquatic system to SDS and heavy metals have not been studied. This study was therefore aimed at investigating the toxicities of SDS and some of the heavy metals found in the river. Dehydrogenase activity in $S$. marcescens was used as microbial response in assessing the toxicities of the SDS and the metals as individual toxicants and in binary mixtures with SDS.

\section{MATERIALS AND METHODS}

\section{Reagents}

The deionized water used in the preparation of chemicals was sterilized by autoclaving and the stock reagents by membrane filtration. The heavy metal ions: $\mathrm{Cd}^{2+}, \mathrm{Pb}^{2+}$, $\mathrm{Zn}^{2+}, \mathrm{Co}^{2+}$ and $\mathrm{Ni}^{2+}$ were used as $\mathrm{CdSO}_{4} \cdot 8 \mathrm{H}_{2} \mathrm{O}, \mathrm{Pb}\left(\mathrm{NO}_{3}\right)_{2}$ $\mathrm{ZnNO}_{3} \cdot 6 \mathrm{H}_{2} \mathrm{O}, \mathrm{CoCl}_{2}$ and $\mathrm{NiSO}_{4} \cdot 6 \mathrm{H}_{2} \mathrm{O}$, respectively. These metals recorded values higher than WHO recommended standards for drinking water in Otamiri river (Okechi \& Chukwura, 2020). These metals, SDS and 3-(4,5-dimethyl-2thiazolyl)-2,5-diphenyl-2H-tetrazolium bromide (MTT) were sourced from Sigma-Aldrich (Germany).

\section{Samples collection}

The sampled area has been described previously (Okechi \& Chukwura, 2020). The river water samples for this study were collected from two sampling points along the river course. The first was adjacent the free zone, motor mechanic village, Nekede $(5.465 \mathrm{~N}, 7.035 \mathrm{E})$, and the second was 100 meters downstream of the first sampling point $(5.463 \mathrm{~N}, 7.034 \mathrm{E})$. These sampled points were down stream of the possible sources of the river contamination by heavy metals and SDS as used in this study. A 75-cL plastic container was used in collecting water sample from each of the two sampled points and thereafter pulled together in a $1.5 \mathrm{~L}$ plastic container. These containers were previously sterilized by soaking in $70 \%$ ethanol for 30 minutes before rinsing severally with sterile deionized water. The sample was taken to the laboratory for analysis, and was refrigerated at $4^{\circ} \mathrm{C}$, until required.

\section{Test organism and culture conditions}

S. marcescens (SerEW01) used in this study was isolated from Otamiri river water as the preponderant bacterial isolate, with $33.33 \%$ occurrence and identified using $16 \mathrm{~S}$ rRNA gene partial sequencing (Okechi \& Chukwura, 2020). Culturing and preparation of test bacterium for toxicity assay was done as described by Nweke et al. (2018). S. marcescens (SerEW01) was grown in nutrient broth and incubated for 16 hours on rotary incubator $(150 \mathrm{rpm})$, at $26 \pm 2^{\circ} \mathrm{C}$. Thereafter, the cells were harvested by centrifugation at $3000 \mathrm{rpm}$ (Newlife Centrifuge, NL80-2) for 15 minutes. Harvested cells were washed thrice in sterile deionized water and then re-suspended in the sterile deionized water. The cell density was adjusted to $1.1 \times 10^{8}$ cells $\mathrm{mL}^{-1}$ based on McFarland turbidity standards.

\section{Binary ratios}

The binary mixtures [SDS $)+\mathrm{Pb}(\mathrm{II}), \mathrm{SDS}+\mathrm{Cd}(\mathrm{II})$, SDS $+\mathrm{Ni}(\mathrm{II}), \mathrm{SDS}+\mathrm{Zn}(\mathrm{II})$, and SDS $+\mathrm{Co}(\mathrm{II})]$ were studied using fixed ratio design as a function of $\mathrm{p}(\%)$ SDS and 100-p(\%) metal ion weight to weight ratios (Table 1). An equieffect mixture (EECR 50) based on the $E C_{50}$ of SDS and a metal ion and three arbitrary combinations (ABCR) were used to evaluate the toxicity of the binary mixtures. In each mixture, the mixture ratio was kept constant, while varying the total concentrations over a range that will enable a complete doseresponse relationship to be obtained. Aqueous stock solutions $(10 \mathrm{mM}$ and $50 \mathrm{mM})$ of the binary mixtures were prepared by combining requisite volumes of the metal ion and SDS 
stock solutions ( $10 \mathrm{mM}$ or $50 \mathrm{mM}$ respectively) to produce a particular concentration ratio.

\section{Toxicity of SDS and individual toxic metal}

The toxicity assay was based on inhibition of dehydrogenase activity in the test bacterium. Dehydrogenase activity measurement is a sensitive, rapid and cheap test to measure microbial growth and viability. Thus, the test has been used to assess chemical toxicity to microorganisms. A modified method of Nweke et al. (2018) was used to assay for dehydrogenase activity. The assay was done using MTT as the artificial electron acceptor. The reaction mixture contained nutrient broth (Lab M), MTT, S. marcescens suspension, SDS or metal ion to a total volume of $2 \mathrm{~mL}(\mathrm{pH} \mathrm{7.0)}$ in $15 \mathrm{ml}$ screw-capped culture tubes. A $0.5 \mathrm{~mL}$ of $0.8 \% \mathrm{w} / \mathrm{v}$ nutrient broth and requisite volumes of SDS $(50 \mathrm{mM})$ or metal ion (10 $\mathrm{mM}$ ) stock solution and sterile deionized water (to make up) were dispensed into triplicate tubes in order to obtain varying concentrations of SDS or metal ion. Thereafter, $0.1 \mathrm{~mL}$ each of $0.1 \% \mathrm{w} / \mathrm{v}$ aqueous solutions of MTT and $S$. marcescens suspension were also dispensed into every tube. The final concentrations of the metal ions ranged between $0.002 \mathrm{mM}$ and $1.5 \mathrm{mM}$ while that of SDS ranged between $1 \mathrm{mM}$ and 10 $\mathrm{mM}$. These concentration ranges were chosen based on the preliminary range-finding tests in order to achieve complete dose-response curve for the toxicants. Control cultures that consisted of inoculated medium without SDS or metal ions were also set up. The cultures were incubated at $26 \pm 2^{\circ} \mathrm{C}$ for 24 hours. Thereafter, the purple-coloured MTT-formazan (MTTF) produced in each tube was extracted in $4 \mathrm{~mL}$ of n-butanol. Absorbance of the extract from each tube was measured in a spectrophotometer (VIS Spectrophotometer $721 \mathrm{D})$ at $590 \mathrm{~nm}$.

\section{Toxicity of binary mixtures}

The toxicity assay method was modified from Nweke et al. (2018). The study was carried out in 2-ml nutrient broth-MTT medium ( $\mathrm{pH}$ 7) supplemented with varying concentrations of SDS and $\mathrm{Cd}(\mathrm{II}), \mathrm{Pb}(\mathrm{II}), \mathrm{Zn}(\mathrm{II}), \mathrm{Co}(\mathrm{II})$ or Ni(II) in triplicate 15 $\mathrm{mL}$ screw-capped culture tubes. Into each tube, $0.5 \mathrm{~mL}$ of 0.8 $\% \mathrm{w} / \mathrm{v}$ nutrient broth, requisite volumes of stock solutions of SDS + metal ion combinations and sterile deionized water (to make up) were dispensed. Thereafter, $0.1 \mathrm{~mL}$ each of $0.1 \%$ aqueous solutions of MTT and $S$. marcescens suspension were added. The final total concentrations of the binary mixtures ranged between $0.05 \mathrm{mM}$ to $3.0 \mathrm{mM}$. The controls consisted of the medium without SDS and metal mixtures. The cultures were incubated at $26 \pm 2^{\circ} \mathrm{C}$ for 24 hours, and subsequently extraction and quantification of MTTF produced were as stated above for individual toxicants.

\section{Estimation of relative responses and $E C_{50}$}

The relative inhibition of dehydrogenase activity $(R)$ was calculated for each tube (Eq. 1).

$$
R=\left[1-\frac{T_{A}}{C_{A}}\right] \times 100
$$

Where, $C_{A}$ is the mean absorbance of MTTF-extracted from the control tubes and $T_{A}$ is absorbance of MTTFextracted from the experiment with various concentrations of the SDS, metal or their mixtures. The concentration-response data of each toxicant and the binary mixtures were encoded into 2-parameter logistic model (Eq. 2) to estimate the $E C_{50}$ as a parameter of the non-linear model.

$$
R=\frac{100}{1+\left(\frac{x}{E C_{50}}\right)^{b}}
$$

Where $x$ stands for toxicant concentration, $E C_{50}$ represents the toxicant concentration that reduced the dehydrogenase activity by $50 \%$ inhibition while $b$ is the slope at $E C_{50}$. In order to estimate, $E C_{50}$ in biphasic concentration-responses, data was fitted into the hormetic model of Schabenberger et al. (1999) (Eq. 3).

$$
R=100-\frac{100-f x}{1+\left[+\left(\frac{2 f E C_{50}}{100}\right)\right]\left(\frac{x}{E C_{50}}\right)^{b}}
$$

Where $f$ determines the extent of hormetic response, $E C_{50}$ is as described in Eq. 2 while the quantity $b$ no longer

\begin{tabular}{|c|c|c|c|c|c|c|c|c|c|c|}
\hline \multirow{3}{*}{ Mixture } & \multicolumn{10}{|c|}{ Mixture Ratios (\%) } \\
\hline & \multicolumn{2}{|c|}{ SDS + Ni(II) } & \multicolumn{2}{|c|}{$\mathrm{SDS}+\mathrm{Cd}(\mathrm{II})$} & \multicolumn{2}{|c|}{$\mathrm{SDS}+\mathrm{Pb}(\mathrm{II})$} & \multicolumn{2}{|c|}{$\mathrm{SDS}+\mathrm{Zn}(\mathrm{II})$} & \multicolumn{2}{|c|}{$\mathrm{SDS}+\mathrm{Co}(\mathrm{II})$} \\
\hline & SDS & $\mathrm{Ni}(\mathrm{II})$ & SDS & $\mathrm{Cd}(\mathrm{II})$ & SDS & $\mathrm{Pb}(\mathrm{II})$ & SDS & $\mathrm{Zn}(\mathrm{II})$ & SDS & $\mathrm{Co}(\mathrm{II})$ \\
\hline EECR 50 & 93.49 & 6.51 & 97.76 & 2.24 & 95.79 & 4.21 & 98.70 & 1.30 & 98.08 & 1.92 \\
\hline $\mathrm{ABCR} 1$ & 94 & 6 & 98 & 2 & 96 & 4 & 99 & 1 & 98 & 2 \\
\hline ABCR2 & 92 & 8 & 96 & 4 & 94 & 6 & 98 & 2 & 96 & 4 \\
\hline ABCR3 & 91 & 9 & 94 & 6 & 93 & 7 & 96 & 4 & 90 & 10 \\
\hline
\end{tabular}
represents the slope at $E C_{50}$ (Cedergreen et al., 2005).

Table 1. SDS and Metal Binary Mixtures

EECR $50=E C_{50}$ equi-effect concentration ratio, $\mathrm{ABCR}=$ Arbitrary concentration ratios 


\section{Prediction of mixture toxicities}

The mixture toxicities were predicted based on the toxicities of the individual toxicants using concentration addition (CA) model (Eq. 4) (Berenbaum, 1985). The concentration addition model assumes that the components of the mixture share common mode of action on target the organism.

$$
E C_{(x \operatorname{mix})}=\left[\sum_{i=1}^{n} \frac{\pi_{i}}{E C_{x i}}\right]^{-1}
$$

In Eq. $4, E C_{x(\text { mix })}$ represents the total mixture concentration that gave $x \%$ inhibition of dehydrogenase activity. $E C_{x i}$ represents the concentration of $i$ th component that produced $x \%$ reduction in dehydrogenase activity when tested as a single toxicant, $n$ is the number of toxicants, $\pi_{i}$ is the relative proportion of $i$ th toxicant in the mixture, On the basis of Eq. 4, the prediction of the mixture toxicities was as reported elsewhere (Nweke et al., 2018).

The independent action (IA) model (Eq. 5) assumed that the components of a given mixture have different mode of action (Faust et al., 2003).

$$
E\left(C_{\text {mix }}\right)=1-\prod_{i=1}^{n}\left[1-E\left(c_{i}\right)\right]
$$

Where $E\left(c_{\text {mix }}\right)$ is the total response (scaled from 0 to 1 ) of an $n$-component mixture, $c_{i}$ is the concentration of the $i$ th component and $E\left(c_{i}\right)$ is the response of each single toxicant. The concentration-response relationships of the individual toxicants were used to determine their response $E\left(c_{i}\right)$, by substituting Eq 2 (scaled 0 to 1 ) into Eq. 5 for each toxicant as Eq 6:

$$
R=\frac{1}{1+\left(\frac{\pi_{i} x}{E C_{50 i}}\right)^{b i}}
$$

The IA model was thus simplified as shown in Eq. 7.

$$
E\left(c_{\text {mix }}\right)=\left[1-\prod_{i=1}^{n}\left\{1-\frac{1}{1+\left(\frac{\pi_{i} x}{E C_{50 i}}\right)^{b i}}\right\}\right] \times 100
$$

Where, $\pi_{i} x$ is the concentration of $i$ th component in the mixture. The $E C_{50}$ and $b$ as calculated from equation 2 for each metal and SDS were used. The effect of the mixture for a total concentration $(x)$ that ranged between 0.02 and $4 \mathrm{mM}$ was computed using Microsoft Excel 2007. The resulting concentrations-effect data were plotted as a line graph to give a visualization of the dose-response curve predicted from the IA model (Nweke et al., 2018).

By using Eq. 7 which was fitted into Microsoft Excel 2007 , the value of $x$ in every mixture that gives $E\left(c_{m i x}\right)$ of $50 \%$ (predicted $E C_{50}$ of mixture) was determined through trials. The $E C_{50}$ of the mixtures based on CA model were determined using Eq. 5 based on the relative proportion and
$E C_{50}$ of each toxicant. The experimental $E C_{50 \mathrm{~s}}$ for individual toxicant as well as for the various mixtures ratios in each mixture were compared. Also, within each mixture ratio, the experimental, CA- and IA-models predicted $E C_{50 \mathrm{~S}}$ were equally compared using Duncan post-hoc tests implemented with SPSS Statistics 21.

\section{Toxic index (TI)}

TI was determined for each mixture by summing the toxic unit of every component of the mixture (Eq. 8).

$$
T I=\sum_{i=1}^{n} \frac{C_{i}}{E C_{50 i}}
$$

Where $C_{i}$ represents the concentration of the $i$ th component in the mixture at the $E C_{50}$ of the mixture $\left(E C_{50 \text { mix }}\right)$ and $E C_{50 i}$ is the concentration of the $i$ th component that reduced dehydrogenase activity by $50 \%$, when tested alone, $\mathrm{TI}=1$ denotes additivity, TI $>1$ shows antagonism while TI $<1$ denotes synergistic interaction (Nweke et al., 2018).

\section{Model deviation ratios (MDR)}

The model deviation ratios were computed using experimental $E C_{50}$, and predicted $E C_{50 \mathrm{~S}}$ (Eq. 9). $\mathrm{MDR}>1$ and $\mathrm{MDR}<1$ indicate underestimation and overestimation of toxicity respectively by the model (Li et al., 2014).

$$
\mathrm{MDR}=\frac{\text { Predicted } E C_{50}}{\text { Experimental } E C_{50}}
$$

\section{Mixture isoboles}

The observed $E C_{50}$ of the mixtures were used to determine the isoboles of the binary mixtures as described by Nweke et al. (2018).

\section{RESULTS}

\section{Toxicity of individual toxicants}

The responses of $S$. marcescens to the toxicity of the toxicants were concentration-dependent. The toxicants increasingly reduced the dehydrogenase activity with increase in concentration, giving percentage inhibitions above $95 \%$ at $1 \mathrm{mM}$ for $\mathrm{Zn}$ (II) and $\mathrm{Ni}(\mathrm{II}), 0.5 \mathrm{mM}$ for $\mathrm{Pb}(\mathrm{II}), \mathrm{Cd}(\mathrm{II})$ and Co(II) and $8 \mathrm{mM}$ for SDS. The dose-response patterns are rather similar for SDS, $\mathrm{Cd}(\mathrm{II})$ and $\mathrm{Co}(\mathrm{II})$ (Figure 1). Table 2 shows the experimental and predicted toxicity thresholds $\left(E C_{50}\right)$ of individual toxicants and their binary mixtures on $S$. marcescens (SerEW01). The $E C_{50 \mathrm{~S}}$ of the toxicants ranged from $0.046 \pm 0.003 \mathrm{mM}$ for $\mathrm{Zn}$ (II) to $2.329 \pm 0.092 \mathrm{mM}$ for SDS. The Duncan test shows that the $E C_{50 \mathrm{~S}}$ of the toxicants differed significantly from one another $(\mathrm{P}<0.05)$ and the order of decrease in toxicity was $\mathrm{Zn}$ (II) $>\mathrm{Cd}$ (II) $>\mathrm{Co}$ (II) $>$ $\mathrm{Ni}(\mathrm{II})>\mathrm{Pb}$ (II) $>$ SDS. 

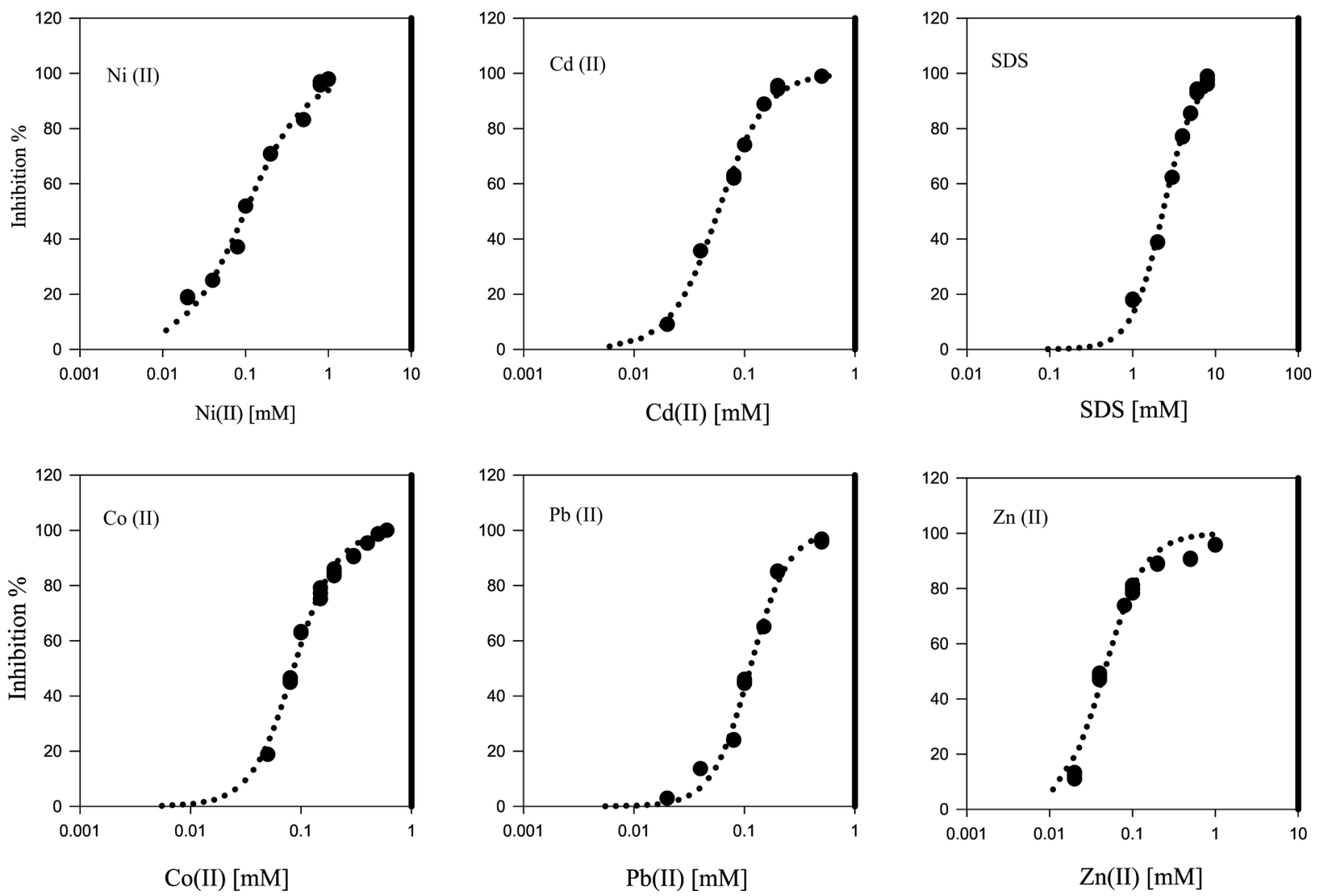

Figure 1. Inhibition of dehydrogenase activity of S. marcescens (SerEW01) by the individual toxicants

\section{Toxicity of binary mixtures}

The experimental concentration-response relationships of the binary mixtures and the predictions from $\mathrm{CA}$ and IA models are shown in Figures 2-6. In SDS 92\% + Ni(II) $8 \%$ (ABCR2) and SDS 91\% + Ni(II) 9\% (ABCR3) mixture ratios, both $\mathrm{CA}$ and IA models slightly over-estimated the toxicities at low concentrations while underestimating at higher concentrations. In other SDS $+\mathrm{Ni}(\mathrm{II})$ mixture ratios, the models predicted slightly lower toxicities than the experimental data would suggest, even at lower concentrations (Figure 2). Also, similar mixture toxicities were predicted by both models, especially for SDS + $\mathrm{Ni}(\mathrm{II})$ mixtures, as their concentration-response curves were almost superimposed. In SDS $+\mathrm{Cd}(\mathrm{II})$ mixtures, inhibition of dehydrogenase activity took place even at low concentrations (Figure 3). Both CA and IA models predicted significantly lower toxicities than the observed. In SDS + $\mathrm{Pb}(\mathrm{II})$ mixtures, the models also grossly underestimated the toxicities relative to the experimental data (Figure 4). As shown in Figure 5, SDS $+\mathrm{Zn}$ (II) mixtures showed that the models slightly predicted lower toxicities, especially for SDS99\% + Zn(II) $1 \%$ (ABCR1) and SDS96\% + Zn(II)4\% (ABCR3) mixture ratios. In SDS + Co(II) mixtures, the equieffect mixture ratio (SDS98.08\% + Co(II)1.92\%) was found to be stimulatory to the dehydrogenase activity at low concentrations and inhibitory at higher concentration. Furthermore, other mixture ratios significantly underestimated the toxicities (Figure 6).
For the binary mixtures (Table 2), the experimental $E C_{505}$ in the SDS $+\mathrm{Ni}$ (II) binary mixture showed that ABCR2 mixture ratio had the highest $E C_{50}(0.314 \pm 0.013 \mathrm{mM})$ while ABCR1 mixture ratio had the least $(0.239 \pm 0.019 \mathrm{mM})$. Also, among the experimental $E C_{50 \text {, }}$, the EECR50 and ABCR2 mixture ratios were statistically different from $A B C R 1$ and ABCR3. In SDS $+\mathrm{Cd}(\mathrm{II})$ binary mixtures, the experimental $E C_{50 \mathrm{~S}}$ ranged from $0.115 \pm 0.007 \mathrm{mM}$ for ABCR2 to $0.207 \pm$ $0.007 \mathrm{mM}$ for EECR50

In $\mathrm{SDS}+\mathrm{Pb}$ (II) binary mixtures, there was no statistical difference between the experimental $E C_{50}$ of EECR50 and ABCR1, as well as between ABCR2 and ABCR3. In SDS + $\mathrm{Zn}(\mathrm{II})$ binary mixtures, $\mathrm{ABCR} 2$ was the most toxic mixture ratio while $\mathrm{ABCR} 3$ was the least. In SDS and $\mathrm{Co}(\mathrm{II})$ binary mixtures, $\mathrm{ABCR} 3$ mixture ratio had the least $E C_{50}(0.149 \pm$ $0.009 \mathrm{mM})$ as against $(0.303 \pm 0.011 \mathrm{mM})$ recorded by EEC50 mixture ratio. In all SDS and metal ion binary mixtures, the experimental, CA- and IA-predicted $E C_{50 \text { s }}$ were statistically different from one another $(\mathrm{P}<0.05)$. Similarly, in all but SDS $+\mathrm{Ni}(\mathrm{II})$ and $\mathrm{SDS}+\mathrm{Pb}$ (II) binary mixtures, the experimental $E C_{\text {sos }}$ for different mixture ratios were also statistically different from one another $(\mathrm{P}<0.05)$.

The toxic index, model deviation ratio and effect of metals and SDS binary mixtures on $S$. marcescens (SerEW01) are shown in Table 3. The toxic index (TI) values ranged from $0.123 \pm 0.002$ to $0.543 \pm 0.007$, while model deviation ratio (MDR) ranged from $1.839 \pm 0.028$ to $10.771 \pm 0.445$. At all the tested mixture ratios, the metals and SDS binary mixtures were synergistic in their action against $S$. marcescens. 
Table 2: Experimental and Predicted Toxicity Thresholds $\left(E C_{50}\right)$ of Individual Toxicants and Their Binary Mixtures on Serratia marcescens (SerEW01)

\begin{tabular}{|c|c|c|c|}
\hline \multirow[b]{2}{*}{ Toxicants } & \multicolumn{3}{|c|}{$E C_{50}(\mathrm{mM})+^{+}$} \\
\hline & Experimental $\uparrow$ & CA-Predicted & IA- Predicted \\
\hline $\mathrm{Na}(\mathrm{II})$ & $0.100 \pm 0.008 \mathrm{a}$ & - & - \\
\hline $\mathrm{Cd}(\mathrm{II})$ & $0.058 \pm 0.002 b$ & - & - \\
\hline $\mathrm{Pb}(\mathrm{II})$ & $0.113 \pm 0.005 \mathrm{c}$ & - & - \\
\hline $\mathrm{Zn}(\mathrm{II})$ & $0.046 \pm 0.003 \mathrm{~d}$ & - & - \\
\hline $\mathrm{Co}(\mathrm{II})$ & $0.086 \pm 0.002 \mathrm{e}$ & - & - \\
\hline SDS & $2.329 \pm 0.092$ & - & - \\
\hline \multicolumn{4}{|l|}{ Binary Mixtures } \\
\hline \multicolumn{4}{|l|}{$\mathrm{SDS}+\mathrm{Ni}(\mathrm{II})$} \\
\hline SDS $93.49 \%$ + Ni $6.51 \%$ (EECR50) & $0.290 \pm 0.016 b^{*}$ & $0.952 \pm 0.064 * *$ & $1.147 \pm 0.027^{* * *}$ \\
\hline SDS 94\% + Ni 6\% (ABCR1) & $0.239 \pm 0.019 \mathrm{a}^{*}$ & $0.998 \pm 0.066^{* *}$ & $1.199 \pm 0.026^{* * *}$ \\
\hline SDS 92\% + Ni 8\% (ABCR2) & $0.314 \pm 0.013 b^{*}$ & $0.838 \pm 0.059 * *$ & $1.012 \pm 0.032^{* * *}$ \\
\hline SDS 91\% + Ni 9\% (ABCR3) & $0.243 \pm 0.010 \mathrm{a}^{*}$ & $0.776 \pm 0.055^{* *}$ & $0.936 \pm 0.035^{* * *}$ \\
\hline \multicolumn{4}{|l|}{ SDS + Cd(II) } \\
\hline SDS $97.76 \%+$ Cd $2.24 \%$ (EECR50) & $0.207 \pm 0.007 \mathrm{a}^{*}$ & $1.241 \pm 0.046^{* *}$ & $1.640 \pm 0.014 * * *$ \\
\hline SDS $98 \%+$ Cd $2 \%(A B C R 1)$ & $0.176 \pm 0.009 b^{*}$ & $1.306 \pm 0.049 * *$ & $1.720 \pm 0.016^{* * *}$ \\
\hline SDS 96\% + Cd 4\% (ABCR2) & $0.115 \pm 0.007 \mathrm{c}^{*}$ & $0.907 \pm 0.033^{* *}$ & $1.188 \pm 0.012^{* * *}$ \\
\hline SDS 94\% + Cd 6\% (ABCR3) & $0.155 \pm 0.008 \mathrm{~d}^{*}$ & $0.695 \pm 0.025^{* *}$ & $0.880 \pm 0.014 * * *$ \\
\hline \multicolumn{4}{|l|}{$\mathrm{SDS}+\mathrm{Pb}(\mathrm{II})$} \\
\hline SDS $95.79 \%+\mathrm{Pb} 4.21 \%$ (EECR50) & $0.251 \pm 0.012 \mathrm{a}^{*}$ & $1.276 \pm 0.053 * *$ & $1.764 \pm 0.009^{* * *}$ \\
\hline SDS $96 \%+\mathrm{Pb} 4 \%(\mathrm{ABCR} 1)$ & $0.249 \pm 0.007 \mathrm{a}^{*}$ & $1.305 \pm 0.055^{* *}$ & $1.804 \pm 0.009^{* * *}$ \\
\hline SDS $94 \%+\mathrm{Pb} 6 \%$ (ABCR2) & $0.193 \pm 0.010 b^{*}$ & $1.070 \pm 0.045^{* *}$ & $1.690 \pm 0.206^{* * *}$ \\
\hline SDS 93\% + Pb 7\% (ABCR3) & $0.201 \pm 0.012 b^{*}$ & $0.982 \pm 0.042 * *$ & $1.331 \pm 0.015^{* * *}$ \\
\hline \multicolumn{4}{|l|}{ SDS + Zn (II) } \\
\hline SDS $98.70 \%+$ Zn $1.30 \%($ EECR 50$)$ & $0.661 \pm 0.015 \mathrm{a}^{*}$ & $1.419 \pm 0.077 * *$ & $1.799 \pm 0.010^{* * *}$ \\
\hline SDS 99\% + Zn 1\% (ABCR1) & $0.725 \pm 0.017 b^{*}$ & $1.560 \pm 0.081 * *$ & $1.941 \pm 0.013^{* * *}$ \\
\hline SDS $98 \%+Z n 2 \%(A B C R 2)$ & $0.310 \pm 0.011 \mathrm{c}^{*}$ & $1.173 \pm 0.068 * *$ & $1.518 \pm 0.017^{* * *}$ \\
\hline SDS 96\% + Zn 4\% (ABCR3) & $0.426 \pm 0.021 \mathrm{~d}^{*}$ & $0.784 \pm 0.050 * *$ & $0.995 \pm 0.032^{* * *}$ \\
\hline \multicolumn{4}{|l|}{ SDS $+\mathrm{Co}(\mathrm{II})$} \\
\hline SDS $98.08 \%$ + Co $1.92 \%$ (EECR 50$)$ & $0.303 \pm 0.011 \mathrm{a}^{*}$ & $1.554 \pm 0.056^{* *}$ & $2.042 \pm 0.026^{* * *}$ \\
\hline SDS $98 \%+$ Co $2 \%$ (ABCR 1$)$ & $0.188 \pm 0.010 \mathrm{~b}^{*}$ & $1.535 \pm 0.058 * *$ & $2.022 \pm 0.024 * * *$ \\
\hline SDS 96\% + Co 4\% (ABCR2) & $0.231 \pm 0.010 \mathrm{c}^{*}$ & $1.142 \pm 0.039 * *$ & $1.547 \pm 0.006^{* * *}$ \\
\hline SDS $90 \%+$ Co $10 \%$ (ABCR3) & $0.149 \pm 0.009 \mathrm{~d}^{*}$ & $0.649 \pm 0.024 * *$ & $0.811 \pm 0.012^{* * *}$ \\
\hline
\end{tabular}

${ }^{+}$Values compiled as Mean $\pm 1 \mathrm{SD}$

$\dagger$ Within columns, in each toxicant mixture type, the experimental $E C_{50}$, values with the same letters are not significantly different from each other $(\mathrm{P}<0.05)$.

$\ddagger$ Within rows, in each mixture ratio, comparing between the experimental $E C_{50}$, CA-predicted $E C_{50}$ and IA-predicted $E C_{50}$, values with the same number of asterisks are not significantly different from each other $(\mathrm{P}<0.05)$.

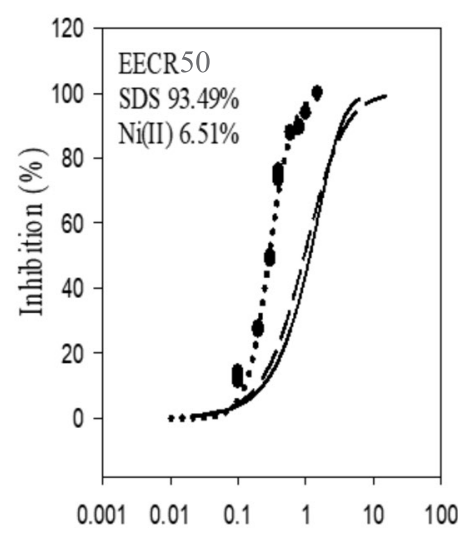

$\mathrm{SDS}+\mathrm{Ni}(\mathrm{II})[\mathrm{mM}]$
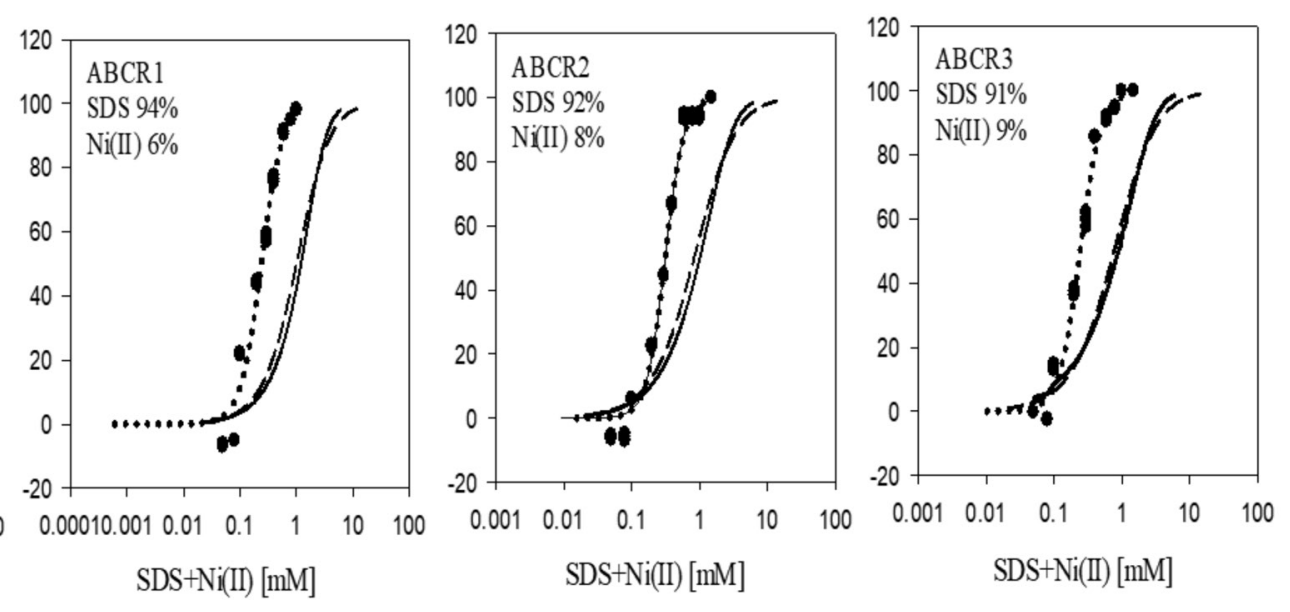

Figure 2. Experimental and predicted effects of binary mixtures of SDS and nickel ions on S. marcescens (SerEW01) dehydrogenase activity. The experimental dose-responses are represented by the data points. The toxicities estimated by fitting experimental data to logistic model (eq. 2 ) are presented as dotted line. The dashed and solid lines indicate the predicted toxicities from concentration addition and independent action models, respectively 


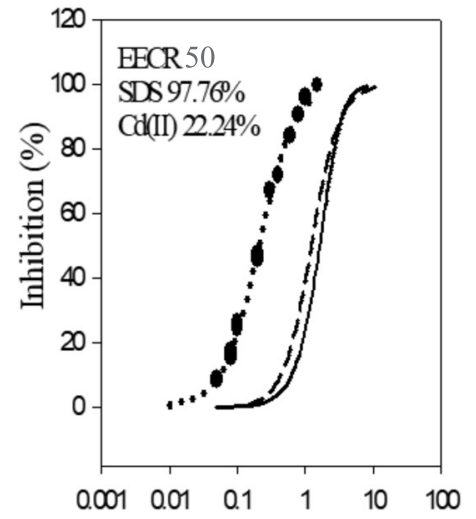

$\mathrm{SDS}+\mathrm{Cd}(\mathrm{II})[\mathrm{mM}]$

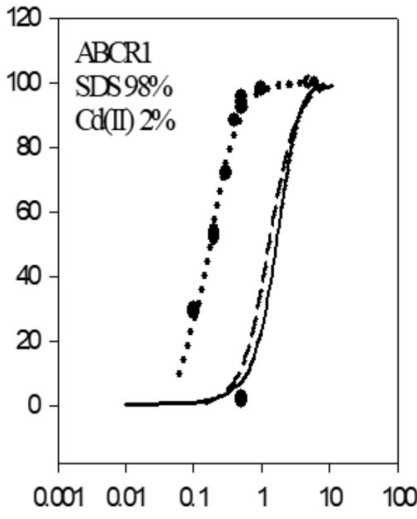

$\mathrm{SDS}+\mathrm{Cd}(\mathrm{II})[\mathrm{mM}]$
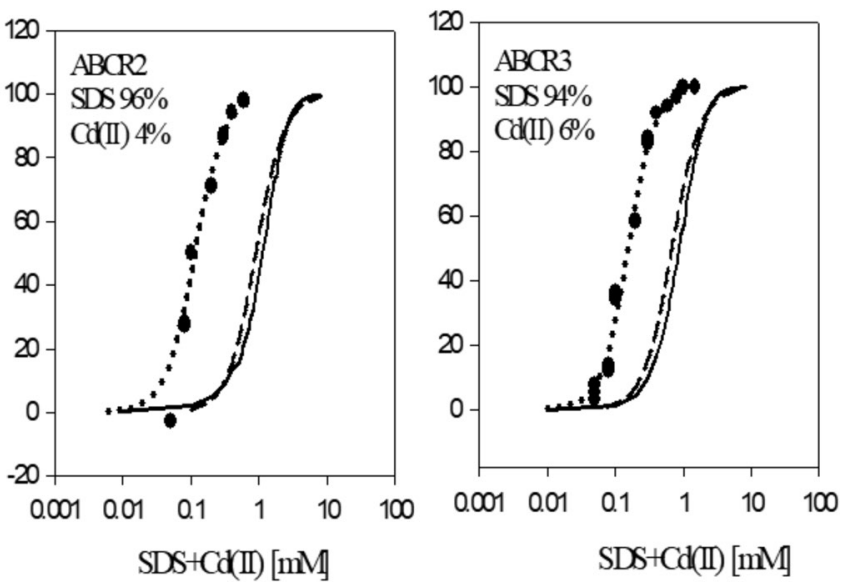

Figure 3. Experimental and predicted effects of binary mixtures of SDS and cadmium ions on S. marcescens (SerEW01) dehydrogenase activity. The experimental dose-responses are represented by the data points. The toxicities estimated by fitting experimental data to logistic model (eq. 2) are presented as dotted line. The dashed and solid lines indicate the predicted toxicities from concentration addition and independent action models, respectively

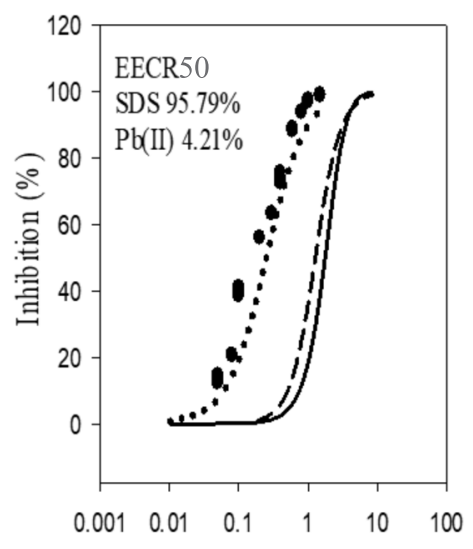

$\mathrm{SDS}+\mathrm{Pb}(\mathrm{II})[\mathrm{mM}]$

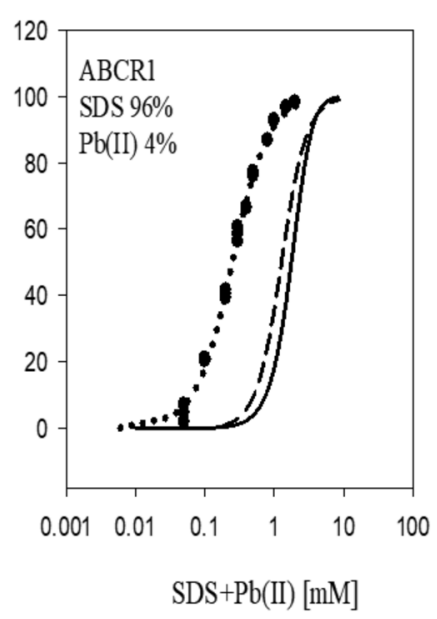

$\mathrm{SDS}+\mathrm{Pb}(\mathrm{II})[\mathrm{mM}]$
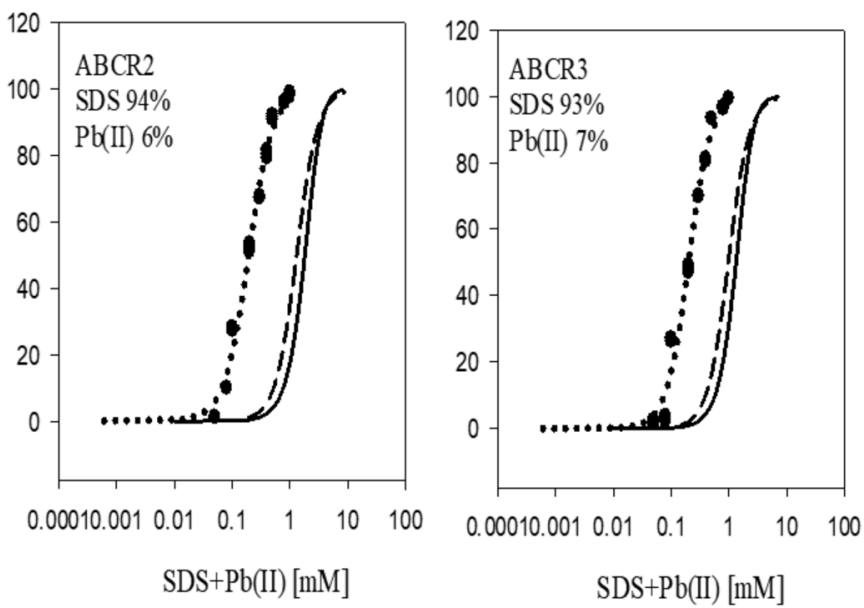

Figure 4. Experimental and predicted effects of binary mixtures of SDS and lead ions on S. marcescens (SerEW01) dehydrogenase activity. The experimental dose-responses are represented by the data points. The toxicities estimated by fitting experimental data to logistic model (eq. 2 ) are presented as dotted line. The dashed and solid lines indicate the predicted toxicities from concentration addition and independent action models, respectively
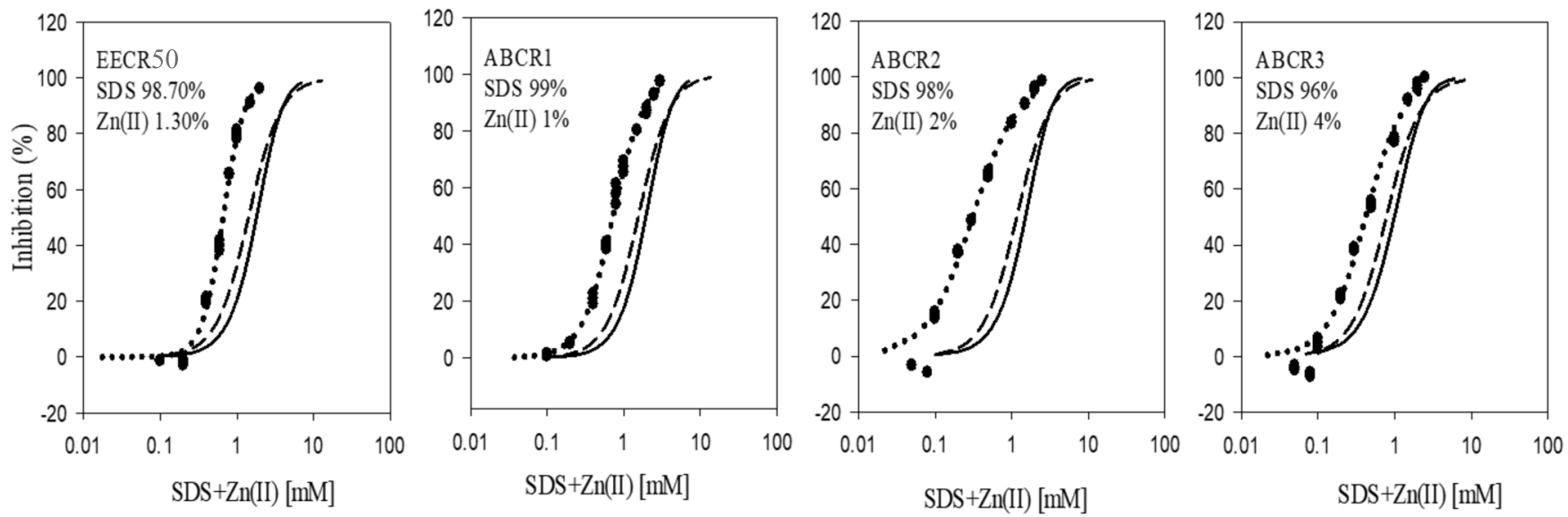

Figure 5. Experimental and predicted effects of binary mixtures of SDS and zinc ions on S. marcescens (SerEW01) dehydrogenase activity. The experimental dose-responses are represented by the data points. The toxicities estimated by fitting experimental data to logistic model (eq. 2) are presented as dotted line.

The dashed and solid lines indicate the predicted toxicities from concentration addition and independent action models, respectively 

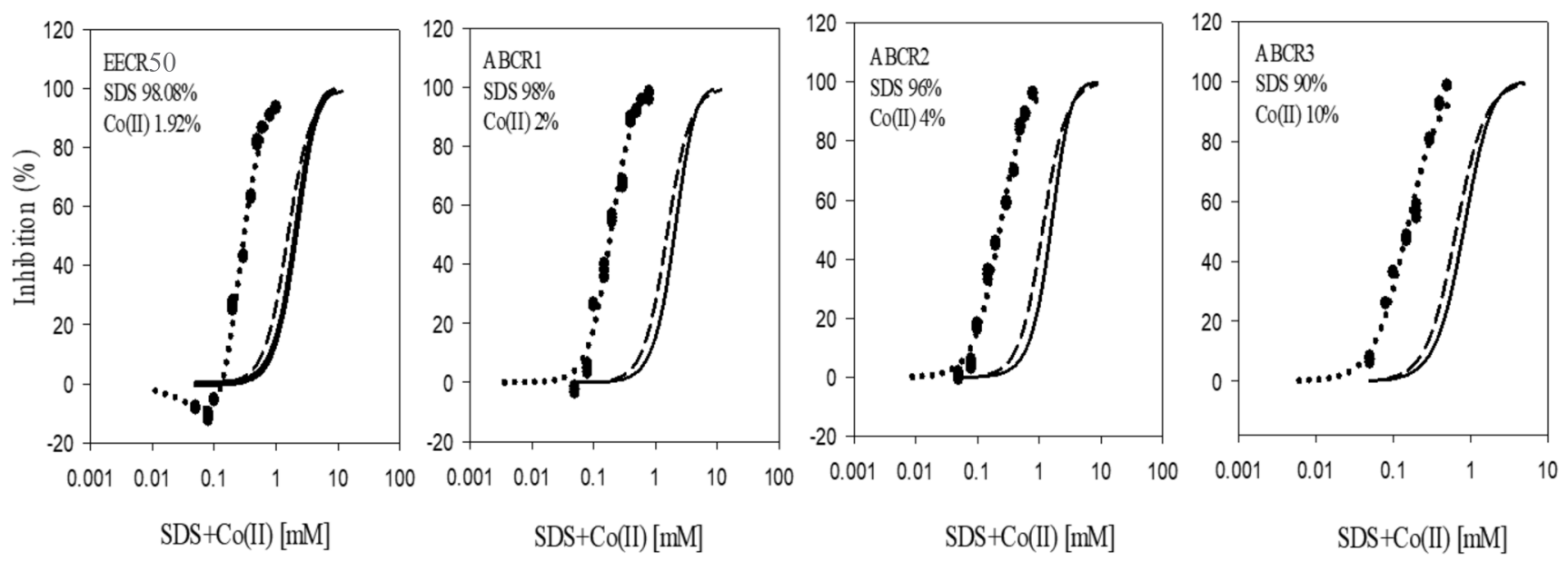

Figure 6. Experimental and predicted effects of binary mixtures of SDS and cobalt ions on S. marcescens (SerEW01) dehydrogenase activity. The experimental dose-responses are represented by the data points. The toxicities estimated by fitting experimental data to logistic model (eq. 2) are presented as dotted line. The dashed and solid lines indicate the predicted toxicities from concentration addition and independent action models, respectively.

The isobologram of the binary mixtures based on the $E C_{50 \mathrm{~S}}$ are shown in Figure 7. The analyses indicate synergistic effect for all metals and SDS binary mixtures ratios on the dehydrogenase activity. This observation was corroborated by the toxic index and model deviation ratios (Table 3).

\section{DISCUSSION}

Zinc, cobalt and nickel are among the trace elements, acting as enzyme co-factors during cell metabolisms. They can however be toxic to microorganisms at high concentrations. These heavy metal ions and SDS were inhibitory to $S$. marcescens (SerEW01) dehydrogenase activity at high concentrations. Heavy metals have been reported to inhibit dehydrogenase activity in pure bacterial cultures and microbial community in both soil and river water by previous authors (Nweke \& Orji, 2009; Nweke et al., 2018). Lead and cadmium have no physiological function in living organisms and inhibit microbial metabolism even at low concentrations, thus they are considered as toxins (Mergeay et al., 1985). Cadmium was reported to compete with cellular zinc resulting in non-specific binding to DNA, inducing single strand breaks (Roane \& Pepper, 2000). The toxic effects of lead include ion substitution or displacement of essential ions from cellular sites and blockade of essential functional groups in enzymes, polynucleotides, and essential nutrient transport systems (Gadd \& Griffiths, 1977).

On the basis of bioluminescence inhibition in photobacterium Q67, median inhibitory concentration $\left(\mathrm{IC}_{50}\right)$ of $0.199 \mathrm{mM}$ to $0.239 \mathrm{mM} \mathrm{Cd(II)} \mathrm{was} \mathrm{reported} \mathrm{by} \mathrm{Ge} \mathrm{et} \mathrm{al.}$ (2014). Similarly, $\mathrm{IC}_{50}$ of $0.022 \mathrm{mMCd}(\mathrm{II})$ against Pseudomonas fluorescens dehydrogenase activity was reported by Nweke et al. (2018). Furthermore, maximum tolerance concentration of 4 $\mathrm{mg} / \mathrm{mL} \mathrm{Pb}(\mathrm{II})\left(\approx 2.0 \times 10^{-5} \mathrm{mM}\right)$ and $1.5 \mathrm{mg} / \mathrm{mL} \mathrm{Cd}(\mathrm{II})\left(\approx 1.3 \times 10^{-}\right.$ ${ }^{5} \mathrm{mM}$ ) were reported for Serratia marcescens by Nwagwu et al. (2017). However, in the present study, median inhibitory concentrations of $0.058 \pm 0.002 \mathrm{mM}$ and $0.113 \pm 0.005 \mathrm{mM}$ were recorded for cadmium and lead respectively. Tolerance of Serratia to zinc and other heavy metals has been reported (Nwagwu et al., 2017; Cider et al., 2017). Similarly, better tolerance to heavy metal toxicity by Gram negative bacteria has also been reported (Minz et al., 1996). A 50\% effective concentration $\left(E C_{50}\right)$ of $0.046 \pm 0.003 \mathrm{mM}$ for zinc was reported in this study, as against $0.180 \mathrm{mM}$ recorded by Nweke et al. (2018) in their study with Pseudomonas fluorescens. Furthermore, an $E C_{50}$ of $0.91 \mathrm{mM}$ was recorded for $\mathrm{Zn}$ against microbial community of new Calabar River (Nweke \& Orji, 2009). Like other heavy metals in the present study, cobalt inhibited dehydrogenase activity in S. marcescens (SerEW01) even at low concentrations. Cobalt was reported to stimulate thermolysin (from Bacillus thermoproteolyticus) activity at low concentrations while inhibiting it at high concentrations (Hashida \& Inouye, 2007). Similarly, nickel stimulation of microbial growth at low concentrations $(<27 \mathrm{mg} / \mathrm{L})(\approx 0.46$ $\mathrm{mM}$ ), has also been reported by Gikas, (2007). In the present study however, cobalt, with an $E C_{50}$ of $0.086 \pm 0.002 \mathrm{mM}$ was more toxic to Serratia marcescens (SerEW01) than nickel $\left(E C_{50} 0.100 \pm 0.008 \mathrm{mM}\right)$. Similar report has been recorded for Pseudomonas fluorescens (Nweke et al., 2018).

There is scarcity of published data on the toxicity of SDS using microbial dehydrogenase activity as a response. In a study that evaluated the effects of SDS on organisms that cut across different phyla, Vibrio fischeri was the most sensitive organism, with an $E C_{50}$ of $2.6 \mathrm{mg} / \mathrm{L}\left(9.02 \times 10^{-3} \mathrm{mM}\right) \mathrm{SDS}$ (Mariani et al., 2006). Sodium Dodecyl sulfate (SDS) recorded an $E C_{50}$ of $2.329 \pm 0.092 \mathrm{mM}$ in the present study, indicating that $S$. marcescens (SerEW01) was probably more tolerant to the effects of SDS than Vibrio fischeri. The variations in responses could be attributed to physiological differences in the organisms or the end point tested. Lopez-Roldan et al. (2012) reported the dependence of toxicity on the conditions in which the test was carried out.

Microorganisms show variations in their metal uptake systems as well as in their ways of accumulating metals 
Table 3: Toxic Index, MDR and Effect of Metals and SDS Binary Mixtures on Serratia marcescens (SerEW01)

\begin{tabular}{|c|c|c|c|c|}
\hline \multirow{2}{*}{ Metal+SDS Binary Mixtures } & \multirow{2}{*}{ Toxic Index (TI) } & \multicolumn{2}{|c|}{$\mathrm{MDR}^{+}$} & \multirow[b]{2}{*}{ Effect } \\
\hline & & $\mathrm{CA}$ & IA & \\
\hline \multicolumn{5}{|l|}{$\mathrm{SDS}+\mathrm{Ni}(\mathrm{II})$} \\
\hline SDS $93.49 \%+\mathrm{Ni}$ (II) $6.51 \%$ (EECR50) & $0.305 \pm 0.004$ & $3.281 \pm 0.040$ & $3.959 \pm 0.125$ & Synergistic \\
\hline SDS 94\% + Ni(II) 6\% (ABCR1) & $0.239 \pm 0.003$ & $4.179 \pm 0.056$ & $5.034 \pm 0.294$ & Synergistic \\
\hline SDS $92 \%+\mathrm{Ni}(\mathrm{II}) 8 \%$ (ABCR2) & $0.375 \pm 0.011$ & $2.671 \pm 0.080$ & $3.228 \pm 0.027$ & Synergistic \\
\hline SDS $91 \%+\mathrm{Ni}(\mathrm{II}) 9 \%$ (ABCR3) & $0.314 \pm 0.009$ & $3.188 \pm 0.089$ & $3.846 \pm 0.027$ & Synergistic \\
\hline \multicolumn{5}{|l|}{$\operatorname{SDS}+\mathrm{Cd}(\mathrm{II})$} \\
\hline SDS $97.76 \%+\mathrm{Cd}(\mathrm{II}) 2.24 \%$ (EECR50) & $0.167 \pm 0.001$ & $5.994 \pm 0.020$ & $7.926 \pm 0.200$ & Synergistic \\
\hline SDS 98\% + Cd(II) 2\% (ABCR1) & $0.135 \pm 0.02$ & $7.425 \pm 0.103$ & $9.785 \pm 0.409$ & Synergistic \\
\hline SDS $96 \%+\mathrm{Cd}(\mathrm{II}) 4 \%(\mathrm{ABCR} 2)$ & $0.127 \pm 0.003$ & $7.900 \pm 0.194$ & $10.349 \pm 0.530$ & Synergistic \\
\hline SDS $94 \%+\mathrm{Cd}(\mathrm{II}) 6 \%(\mathrm{ABCR} 3)$ & $0.223 \pm 0.004$ & $4.489 \pm 0.071$ & $5.682 \pm 0.203$ & Synergistic \\
\hline \multicolumn{5}{|l|}{$\mathrm{SDS}+\mathrm{Pb}(\mathrm{II})$} \\
\hline SDS $95.79 \%+\mathrm{Pb}$ (II) $4.21 \%$ (EECR50) & $0.197 \pm 0.002$ & $5.077 \pm 0.041$ & $7.031 \pm 0.320$ & Synergistic \\
\hline SDS 96\% + Pb(II) 4\% (ABCR1) & $0.191 \pm 0.003$ & $5.240 \pm 0.071$ & $7.247 \pm 0.174$ & Synergistic \\
\hline SDS $94 \%+\mathrm{Pb}(\mathrm{II}) 6 \%$ (ABCR2) & $0.181 \pm 0.001$ & $5.536 \pm 0.039$ & $8.727 \pm 0.757$ & Synergistic \\
\hline SDS $93 \%+\mathrm{Pb}(\mathrm{II}) 7 \%$ (ABCR3) & $0.205 \pm 0.004$ & $4.887 \pm 0.085$ & $6.633 \pm 0.324$ & Synergistic \\
\hline \multicolumn{5}{|l|}{$\operatorname{SDS}+\mathrm{Zn}(\mathrm{II})$} \\
\hline SDS $98.70 \%+\mathrm{Zn}(\mathrm{II}) 1.30 \%$ (EECR50) & $0.466 \pm 0,015$ & $2.146 \pm 0.067$ & $2.723 \pm 0.048$ & Synergistic \\
\hline SDS 99\% + Zn(II) 1\% (ABCR1) & $0.465 \pm 0.013$ & $2.152 \pm 0.062$ & $2.680 \pm 0.045$ & Synergistic \\
\hline SDS $98 \%+\mathrm{Zn}(\mathrm{II}) 2 \%$ (ABCR2) & $0.264 \pm 0.006$ & $3.785 \pm 0.091$ & $4.905 \pm 0.119$ & Synergistic \\
\hline SDS $96 \%+\mathrm{Zn}(\mathrm{II}) 4 \%$ (ABCR3) & $0.543 \pm 0.007$ & $1.839 \pm 0.028$ & $2.337 \pm 0.040$ & Synergistic \\
\hline \multicolumn{5}{|l|}{$\mathrm{SDS}+\mathrm{Co}(\mathrm{II})$} \\
\hline SDS $98.08 \%+\mathrm{Co}(\mathrm{II}) 1.92 \%$ (EECR 50$)$ & $0.195 \pm 0.000$ & $5.129 \pm 0.006$ & $6.743 \pm 0.159$ & Synergistic \\
\hline SDS 98\% + Co(II) 2\% (ABCR1) & $0.123 \pm 0.002$ & $8.168 \pm 0.129$ & $10.771 \pm 0.445$ & Synergistic \\
\hline SDS 96\% + Co(II) 4\% (ABCR2) & $0.202 \pm 0.002$ & $4.939 \pm 0.057$ & $6.694 \pm 0.278$ & Synergistic \\
\hline SDS $90 \%+\mathrm{Co}(\mathrm{II}) 10 \%$ (ABCR3) & $0.230 \pm 0.006$ & $4.371 \pm 0.100$ & $5.462 \pm 0.238$ & Synergistic \\
\hline
\end{tabular}

${ }^{+}$Values compiled as Mean $\pm 1 \mathrm{SD}$
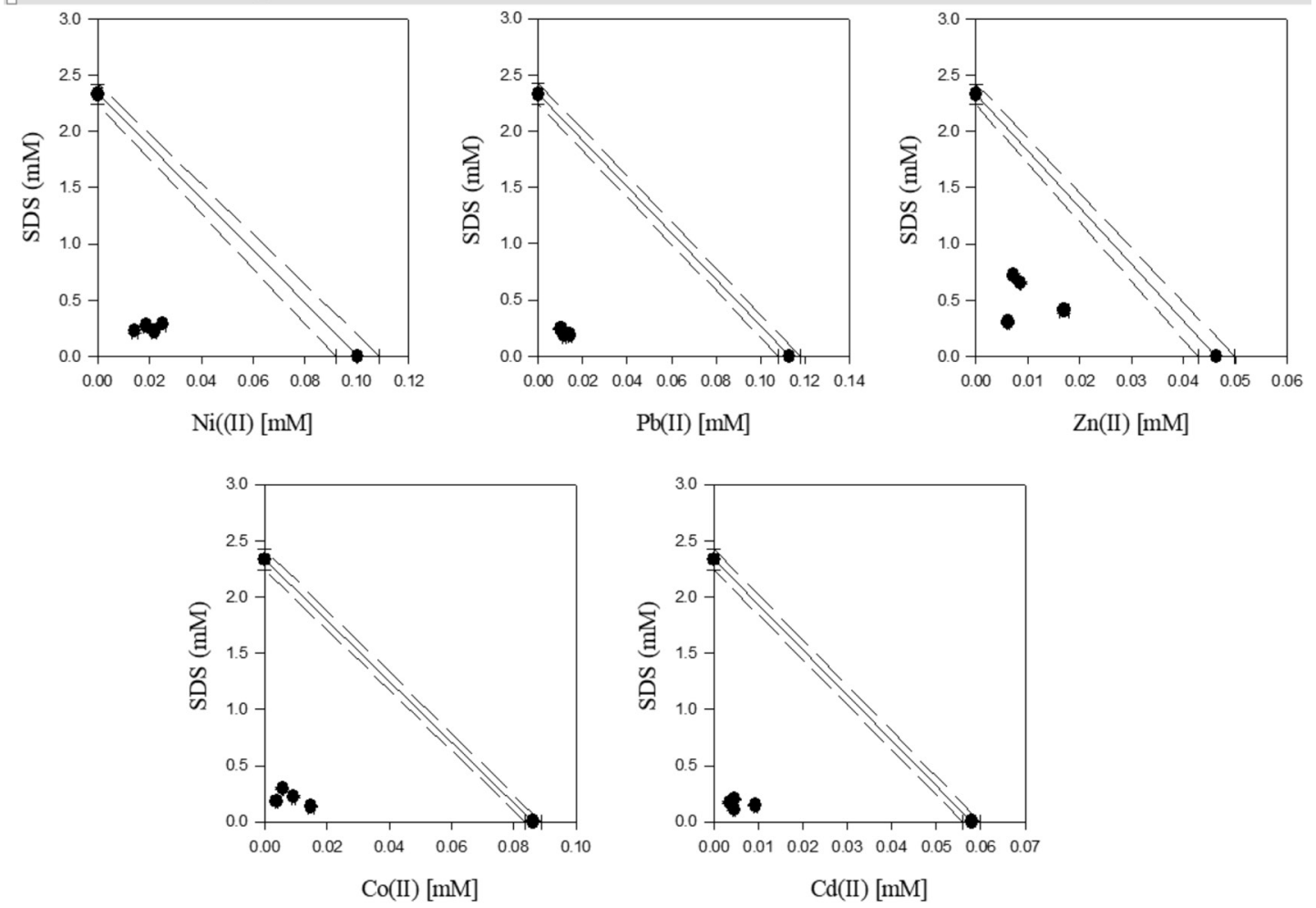

Figure 7. The $E C_{50}$ isobole representation for SDS and metal ions as individual and mixtures tested on dehydrogenase activity of $S$. marcescens (SerEW01). The thick dots represent the standard deviation of the $95 \%$ confidence interval of the values. The solid and dashed lines are additivity lines and their $95 \%$ confidence belt 
inside their cytoplasm. In microorganisms, increase in toxicity of metal ions is expected with proportional increase in concentration. Studies however show that in some cases, higher metal concentrations could trigger-off aggressive resistance mechanisms, thus increasing microbial tolerance to metals (Roane \& Pepper, 2000). The order of toxicity of the toxicants as recorded in this study was $\mathrm{Zn}(\mathrm{II})>\mathrm{Cd}(\mathrm{II})>$ $\mathrm{Co}(\mathrm{II})>\mathrm{Ni}(\mathrm{II})>\mathrm{Pb}(\mathrm{II})>\mathrm{SDS}$. The higher toxicity of zinc compared to cadmium, as well as relative tolerance to lead by this bacterium is not quite understood, although high tolerance of Serratia marcescens to lead and cadmium has been reported (Cristani et al., 2011). Stimulatory effects have been recorded for metal ions against many microbial processes such as dehydrogenase activity, growth and bioluminescence (Roane \& Pepper, 2000; Gikas, 2007; Rodea-Palomares, 2009) and for SDS (Dirilngen and Ince, 1995). However, the absence of stimulatory effects by the individual toxicants as observed in this study could be due to the sensitivity of Serratia marcescens (SerEW01) to the toxicants. The sensitivity of an organism to pollutants has been reported to vary considerably according on the type of pollutant (Wangberg et al., 1995). In addition, the similarity in the shapes of the dose-response curves for some of the toxicants, suggests possible similarity in the molecular mechanisms of action for those toxicants.

Naturally in the environments, microbes are exposed to mixtures of different chemicals whose toxicity often differs from the toxicities of their individual components. Sometimes, interactions may occur between the components of the mixture, resulting in modulation of toxicities of the mixture components. Such phenomenon was observed in this study with SDS and the five heavy metals. SDS modulated the toxicity of the heavy metals and vice versa, giving $E C_{50 \mathrm{~s}}$ higher than those of the individual heavy metals but lower than that of SDS in all the binary mixtures tested. As was observed by Nweke et al. (2018), this modulation seems to be dependent on the relative proportions of the most toxic (heavy metals) and least toxic components (SDS) present in the mixture.

The isobolographic analysis, model deviation ratios and the toxic index model indicated similar effects with respect to the toxicity of SDS and metal mixtures against $S$. marcescens (SerEW01) dehydrogenase activity. The TI values for all the binary mixtures ranged between $0.123 \pm 0.002$ and 0.543 \pm 0.007 , which is less than 1 , thus describing synergistic interaction (Nweke et al., 2018). Similarly, the MDR values for all the binary mixtures ranged from $1.839 \pm 0.028$ to $10.771 \pm 0.445$. Li et al. (2014) suggested that MDR values of less than 0.5 and greater than 2 indicates antagonism and synergism respectively while MDR values of $0.5 \leq \mathrm{MDR} \geq$ 2 indicated additivity. From the present study, all the SDS + metal ion binary mixtures showed synergistic interaction, except SDS $96 \%+\mathrm{Zn}$ (II) $4 \%$ mixture ratio that recorded marginal synergistic interaction. This weak synergistic effect could be attributed to the masking effect of SDS on zinc ions in the mixture. Furthermore, weak synergistic effect was also reported on the analysis of the joint toxicity of copper and perfluorinated carboxylic acids (PFCAs) against
Arthrobacter species (Cai et al., 2019). However, Flores et al. (2010) reported joint toxicity of LAS and anthracene to be antagonistic on the growth of a microbial consortium isolated from polluted sediment

CA and IA models were used in predicting the toxicity of the toxicant mixtures from the concentration-response relationship of the components of the mixture. In SDS 92\% $+\mathrm{Ni}$ (II) $8 \%$ mixture ratio, both models over-estimated the toxicity at low concentrations while underestimating at high concentrations. This is contrary to the observation by other authors on the toxic effects of binary mixtures of heavy metals. For instance, Gikas (2007) while using isobolographic analyses, reported both synergism and antagonism (at the zone of decreasing stimulation) in the binary mixtures of $\mathrm{Ni}(\mathrm{II})$ and $\mathrm{Co}(\mathrm{II})$ against the growth of activated sludge microbial community. Similarly, Nweke et al. (2018) reported underestimation of toxicity at a particular mixture ratio at low concentrations and overestimation at high concentrations of binary mixture of metals to Pseudomonas fluorescens by both models. They therefore concluded that in general, the effect of metal mixtures could depend on the mixture ratio under consideration. Similar assertion could be made about this work, despite the variations in the test bacterium and the toxicants studied. In addition, in SDS 91\% + Ni(II) 9\% mixture ratio, both CA and IA models predicted identical toxicities of the binary mixture. Studies have shown that prediction of similar $E C_{50 \mathrm{~s}}$ by both models is possible under some conditions (Drescher and Boedeker, 1995; Zhang et al., 2008; Huang et al., 2011; Chen et al., 2013).

In SDS + Zn(II) mixtures, both models predicted slightly lower toxicities in various mixture ratios tested. This resulted in weak synergistic interactions between SDS and zinc ions in the mixture. Furthermore, SDS 98.08\% + Co(II) $1.92 \%$ mixture ratio was stimulatory at low concentration and inhibitory at high concentration of the binary mixture. Gikas (2007) reported a more drastic stimulation in the growth of the activated sludge microbial community by the tested $\mathrm{Ni}$ (II) and $\mathrm{Co}$ (II) mixture ratios at relatively low doses, compared to the stimulation by equal concentrations of the individual components, whilst at the same time acting as more potential inhibitors at relatively high concentrations. However, in other SDS + metal ions binary mixtures, both CA and IA models grossly underestimated the toxicities of the mixtures to Serratia marcescens (SerEW01).

\section{CONCLUSION}

The toxicities of the binary mixtures of metal ions and SDS to Serratia marcescens (SerEW01) from a tropical river were determined, using the inhibition of dehydrogenase activity as end point. From the results of this study, both the toxic index (TI) and model deviation ratios (MDRs) analyses showed that the mixture effect was synergistic. Although the result of this study may not be generalizable for all aquatic organisms, it indicates possible synergistic effects of SDS + metal ion mixtures to bacteria. More studies are recommended 
on the effects of the mixtures of these toxicants on the natural microbial community of aquatic ecosystems.

\section{ACKNOWLEDGEMENT}

The financial sponsorship of Tertiary Education Trust Fund (TETFUND), Federal Ministry of Education, Abuja, Nigeria, is gratefully acknowledged. The authors also appreciate the technical supports from Mr B.C. Nzeh and Dr P.E. Asiwe of Federal University of Technology Owerri, Nigeria.

\section{REFERENCES}

AHMAD, R.O., Mohd, T.Y. \& Mohd, Y.S. (2019). Biodegradation of sodium dodecyl sulphate (SDS) by Serratia marcescens strain DRY6. Biorem.Sc. Tech. Res. 7(2): 9-14.

BERENBAUM, M. 1985. The Expected effect of a combination of agents: The general solution. J. Theo. Biol. 114: 413- 431. https://doi: 10.1016/s0022-5193(85)80176-4.

CAI. Y., CHEN, H., CHEN, H., LI, H., SHUO, Y \& WANG, F. 2019. Evaluation of single and joint toxicity of perfluorinated carboxylic acids and copper to metal-resistance Arthrobacter strain. Int. J. Environ. Res. Public Health 16: 135. https://doi: 10.3390/ijerph16010135.

CHEN, J., JIANG, Y., XU, C., YU, L., SUN, D., XU, L., HU, F \& LI, H. 2013. Comparism of two mathematical prediction models in assessing the toxicity of heavy metal mixtures to the feeding of the nematode Caenorhabditis elegans. Ecotox. Environ. Safety, 94: 73-79. https://doi: 10.1016/j.ecoenv.2013.04.026.

CEDERGREEN, N., RITZ, C \& STREIBIG, J.C. 2005. Improved empirical models describing hormesis. Environ. Toxicol. Chem 24 (12): 3166-3172. https://doi: 10.1897/05-014r.1.

CHATURVEDI, A.D \& TIWARI, K.L. 2013. Effect of household detergents (surfactants) degraded through aquatic fungi. Recent Res. Sci. Techno, 5 (5): 12-16.

CIDER, I., PULLIDO, R.P., BURGOS, M.J.G., GALVEZ, A \& LUCAS, R. 2017. Copper and zinc tolerance in bacteria isolated from fresh produce. Journ. Food Prot. 80 (6): 969-975. https:// doi: 10.4315/0362-028X.JFP-16-513.

COWAN-ELLSBERRY, C.S., BELANGER, P., DON, P., DYER, S., MCAVOY, D., SUNDERSON, H., VERSTEEG, D., FERRER, D \& STANTON, K. 2014. Environmental safety of the use of major surfactant classes in North America. Critic. Rev. Environ. Sc. Technol, 44: 1893-1993. https://doi:10. 1080/10739149.2013.803777.

CRISTANI, M., NACCARI, C., NOSTRO, A \& PIZZIMENTI, A. 2011 Possible use of Serratia marcescens in t o x i c metal biosorption (removal). Environ. Sci. Pol. Res. 19 (1): 161168. https://doi: 10.1007/s11356-011-0539-8.

DIRILNGEN, N \& INCE, N. 1995. Inhibition effect of the anionics SDS on duckweed, Lemna minor with consideration of growth and accumulation. Chemosphere, 31: 4185-4197. https:// doi.10.1016/0045-6535(95)80017-F.

DRESCHER, K. \& BOEDEKER, W. 1995. Assessment of the combined effects of substances: the relationship between concentration addition and independent action. Biometric, 51 (2): 716-730. https://doi: 10.2307/2532957

FAUST, M., ALTENBURGER, R., BACKHAUS, T., BLANCK, H., BOEDEKER, W., GRAMATICA, P., HAMMER, V., SCHOLZE, M., VIGHI, M \& GRIMME, L.H. 2003. Joint algal toxicity of 16 dissimilar acting chemicals is predictable by the concept of independent action. Aqua. Toxicol 63: $43-63$. https://doi: 10.1016/s0166-445x(02)00133-9.

FEDEILA, M., HACHAÏCHI-SADOUK, Z., BAUTISTA, L.F., NATECHE, F \& SIMARRO, R. (2018). Biodegradation of anionic surfactants by Alcaligenes faecalis, Enterobacter cloacae and Serratia marcescens strains isolated from industrial wastewater. Ecotoxicol. Environ. Saf. 163:629-635. https://doi: 10.1016/j.ecoenv.2018.07.123.

FLORES, G.P., BADILLO, C.M., CORTAZAR, M.H., HIPOLITO, C.N., PEREZ, R.S \& SANCHEZ, I.G. 2010. Toxic effects of linear alkyl benzene sulfonate, anthracene and their mixtures on growth of a microbial consortium isolated from polluted sediment. Inter. J. Environ. Pol. 26 (1): 39-46.

GADD, G.M \& GRIFFITHS, A.J. 1977. Microorganisms and heavy metal toxicity. Microb. Ecol. 4: 303-317. https://doi. org/10.1007/BF02013274.

GE, H.L., LIU, S.S., SU, B.X \& QIN, L.T. 2014. Predicting synergistic toxicity of heavy metals and ionic liquids on photobacterium Q67. Journ. Haz. Mat. 268: 77-83. https://doi. org/10.1016/j.jhazmat.2014.01.006.

GIKAS, P. 2007. Kinetic responses of activated sludge to individual and joint nickel $(\mathrm{Ni}(\mathrm{II}))$ and cobalt $(\mathrm{Co}(\mathrm{II}))$ : An isobolographic approach. J. Haz. Mat. 143 (1): 246-256. https://doi.org/10.1016/j. jhazmat.2006.09.019

GRIFFITHS, R.P. 1983 The importance of measuring microbial enzymatic functions while assessing and predicting longterm anthropogenic pertubations. Mar. Pol. Bul 14(5): 162-165. https://doi.org/10.1016/0025-326X(83)90225-4.

HASHIDA, Y \& INOUYE, K. 2007. Kinetic analysis of the activation -and-inhibition dual effects of cobalt ion on thermolysin activity. Journ. Biochem. 141: 843-853. https://doi: 10.1093/jb/mvm088.

HUANG, W.Y., LIU, F., LIU, S.S., GE, H.L \& CHEN, H.H. 2011. Predicting mixture toxicity of seven phenolic compounds with similar and dissilmilar action mechanisms to Vibrio qinghaiensis sp.nov.Q67. Ecotox. Environ. Safety, 74 (6): 1600-1606. https:// doi.org/10.1016/j.ecoenv.2011.01.007.

LI, Y., ZHANG, B., HE, X., CHENG, W.H., XU, W., LUO, Y., LIANG, R., LUO, H \& HUANG, K. 2014.

Analysis of individual and combined effects of Ochratoxin A and Zearalenone on $H e p G 2$ and $K K-1$ cells with mathematical models. Tox. 6: 1177 - 1192. https://doi:10.3390/toxins6041177.

LOPEZ-ROIDAN, R., KAZLAUSKAITE, L., RIDO, J., RIV, M.C, GONZALEZ, S \& CORTINA, J.L. 2012. Evaluation of an automated luminescent bacterial assay for in situ aquatic toxicity determination. Sci. Tot. Environ. 440: 307-313. https://doi. org/10.1016/j.scitotenv.2012.05.043,

MARIANI, L., DE PASCALE, D., FARAPONOVA, O., TORNAMBE, A., SARNI, A., GIULIANI, S., RUGGIERO, G., ONORATI, F \& MAGALETT, E. 2006. The use of a test battery in marine ecotoxicology: The acute toxicity of sodium dodecyl sulfate. Environ. Toxicol. 21: 373-379. https://doi.org/10.1002/ tox.20204.

MERGEAY, M., NIES, D., SCHLEGEL, H.G., GERITS, J., CHARLE, P \& GIJSEGEN, F 1985. Alcaligenes eutrophus CH34 is a facultative chemolithotroph with plasmid-bound resistance to heavy metals. Journ Bacteriol. 62: 328-334.

MINZ, D., ROSENBERG, E \& RON E.Z. 1996. Cadmium binding bacteria: screening and characterization of new isolates and mutants. FEMS Microbio. Let. 135: 191-194. https://doi. org/10.1111/j.1574-6968.1996.tb07988.x.

NWAGWU, E.C., YILWA, V.M., EGBE, N.E \& ONWUMERE, G.B 2017 Isolation and characterization of heavy metal tolerant bacteria from Panteka stream, Kaduna, Nigeria and potential for bioremediation. Afr. J. Biotech 16 (1): 32-40. https://doi: 10.5897/AJB2016.15676.

NWEKE, C.O \& ORJI, J.C. 2009. Toxicity of heavy metals to 
microbial community of new Calabar river. Nig. J.

Biochem. Mol. Biol. 24 (1): 48-54.

NWEKE, C.O., UMEH, S.I \& OHALE, V.K.. 2018. Toxicity of four metals and their mixtures to Pseudomonas fluorescens: An assessment using fixed ratio design. Ecotox. Environ. Cont 13 (1): 1-14. https://doi: 10.5132/eec.2018.01.01

OGA, J.O., OGAH, R.O \& UBAKA, K.G. 2018. Bacteriological assessment of water from Otamiri river in Owerri Imo State. Inter. J. Chem. Chem. Proc 4 (2): 2545-5265.

OGBULIE, T., OGBULIE, J.A.N. \& UWAZURUIKE, I. (2010). Biodegradation of detergents by aquatic bacterial flora from Otamiri River, Nigeria. Afr. J. Biotech. 7(6): 824-830.

OKECHI, R.N \& CHUKWRA, E.I 2020. Physicochemical and bacteriological qualities of Otamiri river water and sediment in South Eastern Nigeria. Front. Environ. Microbiol 6(2): 18-26. https://doi:10.11648/j.fem.20200602.12.

ONYEKURU, S.O., NWANKWOALA, H.O \& UCHECHUKWU, E.I. 2017 Heavy metal analysis of Otamiri river in Imo State, Southeastern Nigeria. Journ of Eco. Nat. Res 1 (3): 1-6. https:// doi.org/10.1016/0025-326X(83)90225-4.

ROANE, T.M \& PEPPER, I.L, 2000. Microorganisms and metal pollutants: In: Maier RM, Pepper IL, Gerba CP (eds) Environmental microbiology. New York, Academic Press. p 408.

RODEA-PALOMARES, I., GONZALEZ-GARCIA, C., LEGANES,
F \& FERNANDEZ-PINAS, F. 2009. Effect of pH, EDTA and anions on heavy metal toxicity towards a bioluminescent cyanobacterial bioreporter. Achiev Environ. Cont. Toxicol. 57 (3): 477-487. https://doi: 10.1007/s00244-008-9280-9.

SCHABENBERGER, O., THARP, B.E, KELLS, J.J \& PENNER, D. 1999. Statistical test for hormesis and effective dosages in herbicide dose-response. Agro. Journal, 91: 713-721. https://doi. org/10.2134/agronj1999.914713x

SEIFERT, K \& DOMKA, F 2005. Inhibiting effect of surfactants and heavy metal ions on the denitrification process. Pol. J. Environ. Stud, 14 (1): 87-93.

SINGER, M.M \&TJEERDEMA, R.S 1993. Fate and effects of the surfactant sodium dodecyl sulfate. Rev. Environ. C o n t . Technol 133: 95-149. https://doi: 10.1007/978-1-4613-952943 .

WANGBERG, S-A., BERGSTROM, B., BLANCK, H., \& SVANBERG, O. 1995. The relative sensitivity and sensitivity patterns of short-term toxicity tests applied to industrial wastewaters. Environ. Toxicol. Water Qual. 10 (2): 81-90. https://doi.org/10.1002/tox.2530100202.

ZHANG, Y.H., LIU S.S., SONG X.Q \& GE H.L 2008. Prediction for the mixture toxicity of six organophosphorus pesticides to the luminescent bacterium Q67. Ecotoxicol and Environ. Safety, 71: 880-888. https://doi.org/10.1016/j.ecoenv.2008.01.014. 